CENTER FOR DISEASE CONTROL

NATIONAL INSTITUTF FOR OCCUPATRONAL SAFETY AND HEALTH

C NCINNATL, OHIO 45202
HEALTH HAZARD EMUATION DETERMIMATION REPORT 73-93-199
DUNLOP TIRE AND RUBBER COMPAIY
HUNTSVILLE, ALABAMA

JUNE 1975

I. TOXICITY DETERMINATION

Based on the results of environmental/medical evaluations, as conducted by the National Institute for Occupational Safety and Health (MIOSH) on June 17-20, 1974, it was determined that mil7 room employee exposures to zinc oxide, manganese and copper were not toxic at the concentrations measured.

The presence of excessive concentrations of airborne particulate matter in both the mill room and maintanance shop were found to exist. These levels exceeded all hygienic standars including the Federal Standards for nuisance dusts. Although the maxicity of these dusts is not known at this time, there is no particulate which does not evolve some cellular response in the lung when inhaled in sufficient amount. Therefore, its control is considered to be of utmost importance. Numerous recommendations were made to assist management in a necessary reduction of measurad levels.

No cases of current dermatitis were found among the thirty (30) workers interviewed and examined. It should be noted, however, that several individuals have experienced dematitis which is historically compatible with contact dermatitis of occupational origin, and that several substances are currently utilized which are known cutaneous sensitizers. Thus, the possibility that further cases of allergic contact dermatitis may occur is very real, and the current medical situation should not give rise to complacency.

II. DISTRIBUTION AND AVAILABILITY

Copies of this Determination Report are available upon request from the Hazard Evaluation Services Branch, NIOSH, U. S. Post Office Building, Room 508, 5th and Walnut Streets, Cincinnati, Ohio 45202. Copies have been sent to:

(1) Dunlop Tire and Rubber Company, Huntsville, Alabama

(2) Authorized Representative of Employees

(3) U. S. Department of Labor - Region IV

(4) MIOSH - Region IV

For the purpose of informing the "affected employees", the amployer will promptly "post" the Determination Report in a prominent place(s), rear where approximately eighty (80) affected employees work, for a period of thirty (30) calendar days.

III. INTRODUCTION

Section 20 (a) (6) the Occupational Safety and Health Act of 1970, 29 U.S.C. 669 (a) (6), authorizes the Secretary of Health, Education, and Welfare, following receipt of a written reouest from any employer or authorized representative of tomloves, to determing whether any substance normally found in the place of employment has potentially toxic effects in sucn concentrations as used or found: 
Page 2 - Health Hazard Evaluation Determination Report 73-93

The Gational Institute for Occupational Safety and Heal th received such a request from an authorized representative of employees to evaluate the potential hazard associated with employee exposure to dust in the:
(a) mill room, and (b) maintenance shop.

\section{HEALTH HAZARD EVALUATION}

\section{A. Description of Process}

This modern industrial facility has been in operation approximately five (5) years and produces automotive passenger tires exclusively. At the time of the survey, approximately 500 persons were employed with 363 classified as production workers and forty-seven (47) as maintenance employees.

The process used is similar to that of most rubber tire manufacturers, and includes the normal operation of the crude rubber bale cutters, three (3) Banbury mixers and the power-driven horizontal two-roll mills. Batches of rubber are initially compounded by placing pre-weighed amounts of raw materials on conveyors which feed the Banbury mixers. These materials consist principally of natural rubber, synthetic rubber, fillers, pioments, accelerators and inhibitors. Carbon black is automatically conveyed into the mixer(s) unless the conveyer system is inoperative. The majority of master batches which are then used in formulating other rubbers, are mixed in Banbury No. 1. Following the initial blending in the Banbury mixers, var-ous raw rubbers are conveyed to the mills for further blending to ultimately produce the rubbers actually needed for tire fabrication.

The Vacu-Blast macnine is located in the northwest corner of the maintenance shop, is fully enclosed, and utilized glass "beads" as an abrasive in cleaning tire molds. The "beads" are made from glass plate which has been crushed and sterlized. The operation is sporadic, but is performed several hours per week. Operator exposure is minimal, but some dust escapes from the enclosure and settles out on the maintenance room equipment.

\section{B. Study Progress and Design}

On November 2, 1973, an initial walk-through survey of the facility was conducted by NIOSH representative, Mr. Harry L. Marke?, Jr., who was accompanied by representatives of both management and the United Rubber Workers of America, Local \#915.

Work practices were observed and the local exhaust ventilation system was evaluated by making random checks with air flow indicators (smoke tubes) and an ALNOR JR. velometer. Seven (7) employees, known to have previously registered complaints relating to medical or environmental situations, were briefly interviewed during the course of the walk-through survey. None voiced complaints at that time. 
Page 3 - Health Hazard Evaluation Determination Report 73-93

Based on observations made and impressions obtained during the initial survey, it was concluded that further environmental evaluation(s) would be desirable in both the mill room and maintenance shop. When making the decision on which chemicals would be evaluated, consideration was given to:

(a) medical information/data obtained from employees; (b) nature of operation; (c) process changes; and (d) frequency/duration of exposure.

In addition, the original requestor of the Health Hazard Evaluation asked that a medical evaluation be made of dermatitis cases allegedly occurring in the mill room from chemicals used in compounding various rubber formulations. The above mentioned environmental/medical evaluation was performed June $17-20,1974$.

C. Evaluation Methods

1. Zinc oxide fume, Manganese and Copper fume

Work area air samples were collected by using MSA battery-operated vacuum pumps with AAWP cellulose membrane filters at a sampling rate of 1.7 Titers per minute for periods of one (1) to six (6) hours, Samples (personal breathing-zone and area) were analyzed, by atomic absorption spectroscopy, for both total and respirable amounts of contaminant.

\section{Particulate Matter}

Work area air samples were collected by using MSA battery-operated vacuum pumps with tared PuC, 5 ou filters at a sampling rate of 1.7 Titers per minute for periods of one (1) to six (6) hours. Samples (personal breathing zone and area) were analyzed by the gravimetric weight difference method.

\section{Evaluation Criteria}

\section{Environmental Standards}

(a) Air contaminants -. Current and available information, relating human toxicity with exposure to substances and conditions, has been reviewed for compounds applicable to this survey. On the basis of this review, the values recommended by the American Conference of Governmental Industrial Hygienists, Threshold Limit Value Comittee are applied to this survey. 


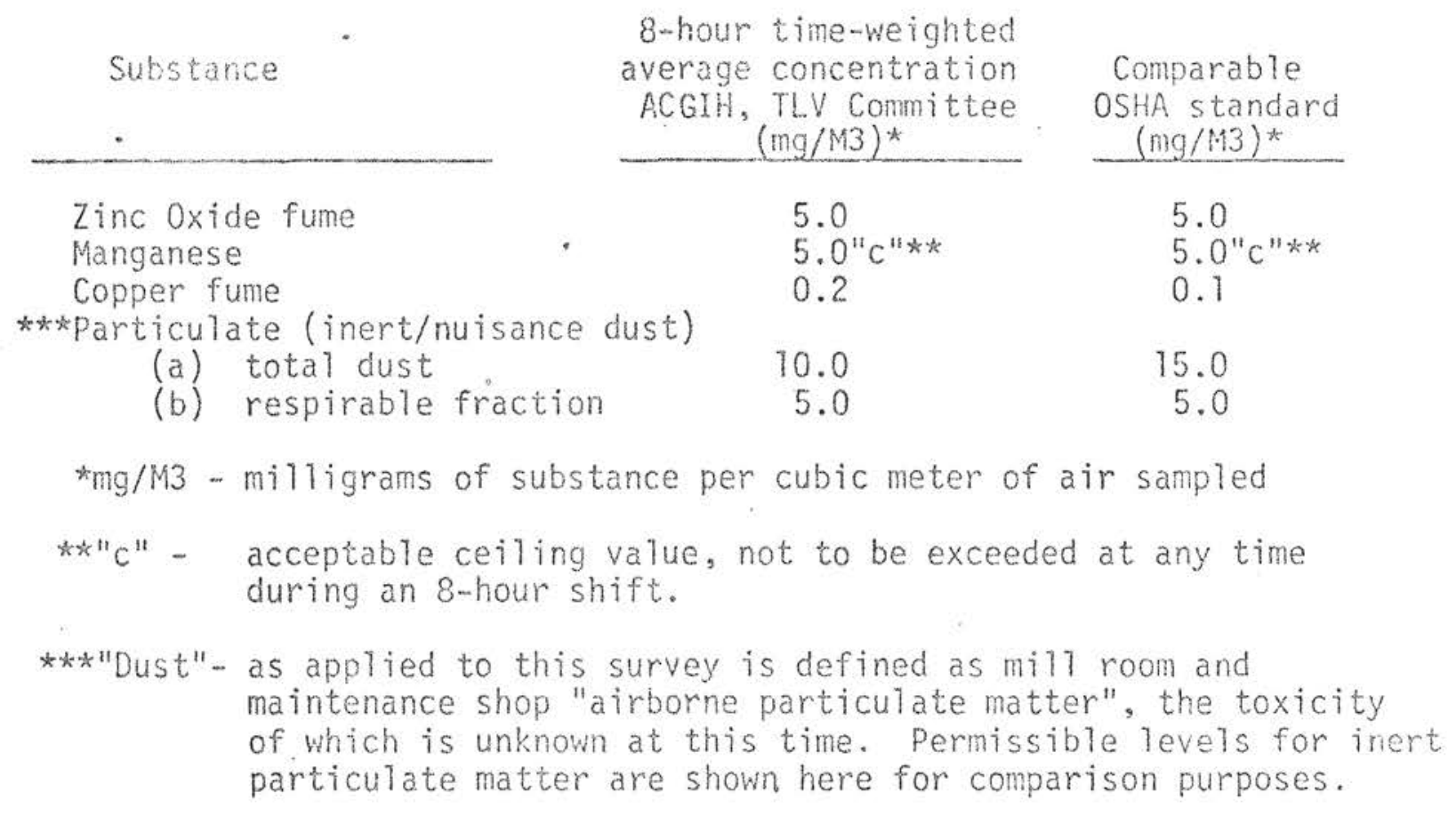

E. Evaluation Results and Discussion

\section{Environmental}

The results of the 147 air sample analyses (34-Zinc Oxide; 34-Manganese; 34-Copper: 45-Particulate matter) performed during the June 18-20, 1974, environmental survey are shown in Tables 1 through 3 . As can be seen from the tables, all concentrations of zinc oxide, manganese and copper, as measured in the mill room work area(s) were wel? below recommended levels and/or applicable standards.

Concentrations of airborne particulate matter measured in the mill room and maintenance shop, are shown in Tables 1 and 2 . These values do not, in reality, represent 8-hour time-weighted concentrations due to the fact that process changes, etc., in some instances necessitated the collection of short-term air samples.

The chemical composition of these dusts could not be specifically determined since they are highly complex and formulations are variable. Their toxicity is not known at this time; however, permissible levels and/ or applicable standards for nuisance dust might be applied for comparison purposes. After giving due consideration to the concentrations measured during the actual sampling periods utilized, projected 8-hour time-weighted average concentrations might well be considered "excessive".

Although the Health Hazard Evaluation request, as initially received, made mention of: (a) carbon black dust in the mill room, and, (b) fiberglas dust in the maintenance shop, no specific evaluation was made for the reasons listed below. 
On inhalation, carbon particles may be retained in the lungs without significant effects. Carbon black, because of its particle size -averaging 25-35 millimicrons--can cause obstruction of cutaneous pores resulting in a dermatitis of short duration. Carbon black contact is, however, minind at this facility. It is metered directly into the Banbury mixer(s), and contact is not required unless a mafunction of the automatic conveyor necessitates manual loading.

Dust escaping from the Vacu-Blast machine is not of the "fiberglas" variety, but rather a glass dust which does not contain free silica and which, therefore, cannot produce silicosis. Glass powder can cause a mechanical dermatitis, especially if trapped between the skin surface and clothing, e.g., cuff and collar areas.

\section{Medical}

A total of thirty (30) mill room employees, representing all three (3) shifts, were interviewed on June 17-20, 1974, in a nondirected namner by James B. Lucas, M.D., the NIOSH physician. Employees responding positively to subsequent direct questioning, or initially volunteering cutaneous or other relevant complaints, were then interviewed more fully and examined in private.

No current cases of dematitis were encountered. Seven (7) individuals currently employed in the mill room gave histories of dermatitis. Briefiy, these episodes may be characterized as follows:

a. History. of a transient rash when first employed. No problem for several years.

b. Dermatitis attributed to handing "raw green rubber" approximately two years prior to this survey. This use of this type of rubber was discontinued shortly thereafter.

c. Rash on arms when handling carbon black manually. This is not a current problem unless the automatic carbon biack conveyor is down for repairs and manual loading is necessitated. This rash, as described, seems typical of that produced by the mechanical obstruction of skin pores.

d. Rash on arms and chest approximately six months prior to this survey, which the employee attributed to hexamethylenetetramine (Code $\$ 33-838$, The individual who reported this has had no health problems since that time, and declined the opportunity to be patch tested to the suspect substance.

e. Rash occurring approximately one year ago and which may possibly be attributed to 2-morpholinothiobenzothiazole (Code $\$ 33-606$ ). No problem has been reported since that time.

f. Multiple bouts of dermatitis (over a five year period), with the last subsiding four months ago. Patch test was performed by a lucal dermatologist (8 tests) with all negative results. This dermetts had involved the entire body after berimming on the arms and chort. No lesions were in evidence on examination. 
Page 6 - Health Hazard Evaluation Detemination Report 73-93

g. Two previous bouts of dematitis involving the groin and legs. On examination, the skin was dry, but without evidence of current dermatitis.

Both of the latter two individuals were patch tested at their request in an attempt to clarify the nature of the previous dermatitis and its possible occupational origin. One percent concentrations of .2-morpholinothiobenzothiazole (Code \#33-606), alkylphenol disulfide (Code \#33-845), resorcinol mixture (Code \#34-840), sodium silicoaluminate (Code \#31-890), and hexamethylenetetramine (Code \#33-838) in petrolatum were applied under A7-test patches along with a plain petrolatum control patch and read at 48 hours. All tests in both men were completely negative, indicating the absence of contact allergy to the substances tested.

of the three (3) previous mill room employees who were also interviewed and examined, one gave a history of dermatitis compatible with occupational allergic contact dermatitis. He was patch tested by a local dermatologist and found to be allergic. His transfer was not prompted by the dermatitis, which cleared, under treatment, while he was still employed in the mill room. He has had no further problem since that time, and is now no longer exposed. The two (2) other previous mill room employees were determined to have had non-occupationally related types of dermatitis. One individual who periodically operates the Vacu-Blast machine was interviewed and found to be totally asymptomatic.

In the course of interviewing/examining the thirty (30) employees, no cases of current dermatitis were found, and relatively few symptoms or complaints were elicited.

\section{F. Conclusions}

Based on the combined enviromental/medical findings, is concluded that at the time of the study, no evidence was found to suggest that the substances utilized in the mill room or maintenance shop areas were producing toxic effects among the exposed work force. It should be noted, however, that several individuals have experienced dermatitis which is historically compatible with contact dermatitis of occupational origin, and that several substances are currently utilized which are known cutaneous sensitizers. Thus, the possibility that future cases of allergic contact dermatitis may occur is very real and the current situation should not give rise to complacency.

V. RECOMMENDATIONS

1. Careless handling of chemicals was consistently observed in the mill room. A considerable amount of dust was being generated while weighing/ mixing bulk chemicals (zinc oxide, etc.) and depositing them on conveyors leading to the Banbury(s). Care should be taken to prevent excessive amounts of fugitive dust created from weighing/mixing operations. In addition, and where possible, "dumping" should occur as close to the face of the Banbury as possible, thus allowing maximum collection efficiency from existing exhaust ventilation. 
2. Ventilation in the "hole" area beneath \$1 and $\$ 2$ Banbury(s) was deemed to be inadequate. The volume of fresh air currently being supplied should be increased.

3. Where possible, the use of compressed air for cleaning purposes in both the mill room and maintenance shop should be minimized. Where such practice is deemed absolutely necessary for cleaning bags, equipment, etc., it should be performed by persons wearing approved dust respirators, and in a manner so as to expose a minimal number of employees.

4. In order to insure the proper operation of the Vacu-Blast machine, as currently located in the maintenance shop, filters should be changed at appropriate intervals and maintained in a clean condition at all times.

5. Based on the existence of high concentrations of dust, whose toxicity has not been characterized, in both the mill room and maintenance shop, it is further recommended that:

a. Approved dust respirators be worn by employees performing duties in those related areas in the interim until it can be demonstrated that such excessive exposures are permantly eliminated via the implementation of either the recommended procedures outlined above or other appropriate engineering and/or administrative controls.

b. Annual chest $X-r a y$ and pulmonary function examinations be performed on those same employees.

c. Management conduct, at reasonable intervals, a program of selfevaluation, whereby a determination is made of air quality/levels of employee exposure in the applicable work areas. (Note - the results of these evaluations may, in turn, determine the need for, and degree of engineering controls, respirator usage, medical examinations, etc.).

VI AUTHORSHIP AND ACKNOWLEDGEMENT

Report prepared by:

Laboratory Analyses:

Originating office:
Harry L. Markel, Jr.

Regional Industrial Hygienist-NIOSH

Region VI, Dallas, Texas

James B. Lucas, M.D.

Medical Services Branch-NIOSH

Cincinnati, Ohio

Staff, Physical and Chemical Analysis Branch, Division of Laboratory and Criteria Developmen Cincinnati, Ohio

Richard Kupel, Chemist

Robert L. Larkin, Chemist

John L. Holtz, Chemist

Robert $W$. Kerimo, Chemist

John C. Carter, Technician

Jerome P. Flesch, Chief

Hazard Evaluation Services Branch-NIOSH

Cincinnati, Ohio 
Table 1

Concentrations of particulate Matter

Duniop Tire and Rubber Company Mill Room

Huntsvilie, Alabama

June 18-20, 1974

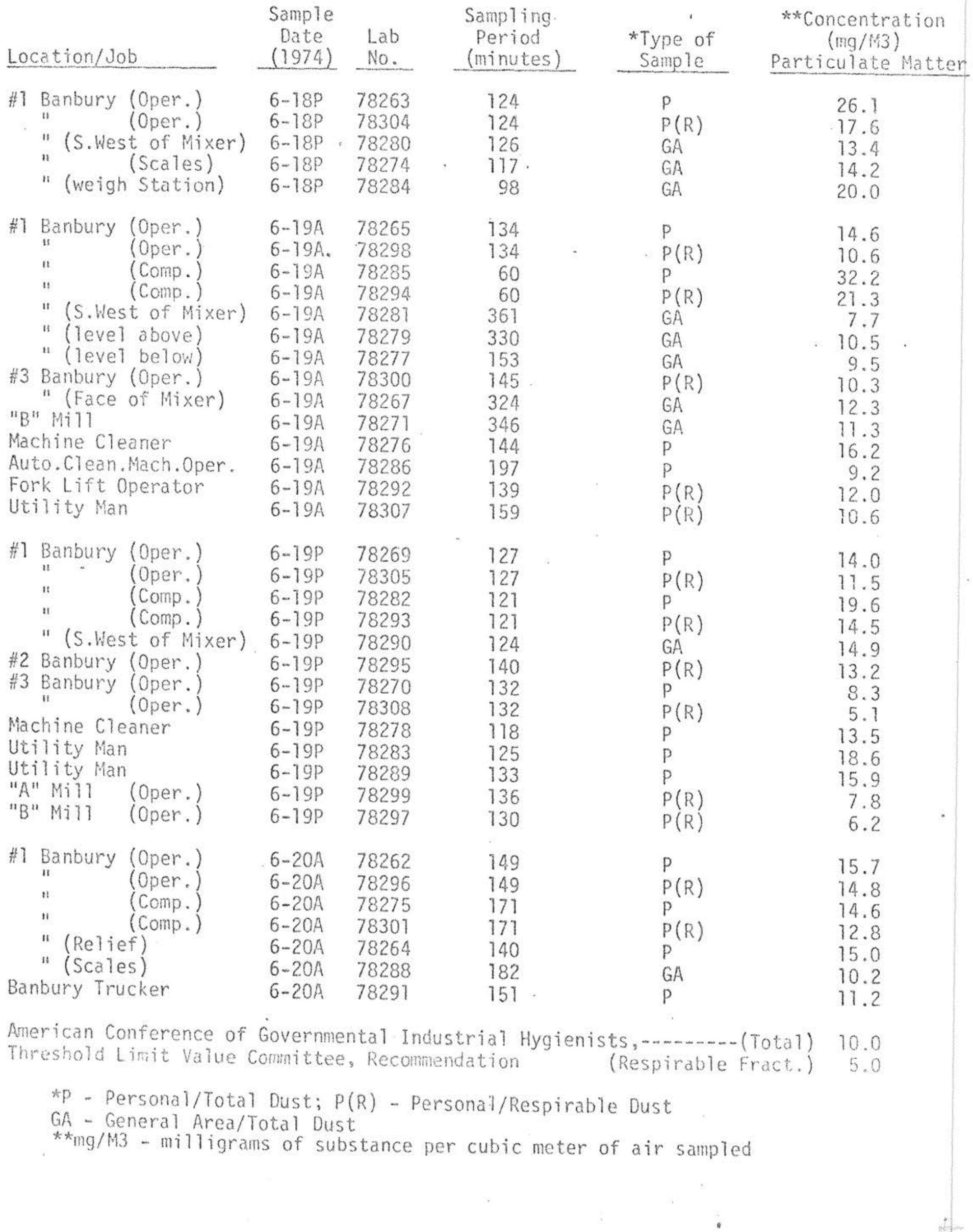


Table 2

Concentrations of Particulate Matter

Dunlop Tire and Rubber Company Maintenance Shop Huntsville, Alabama June $18-20,1974$

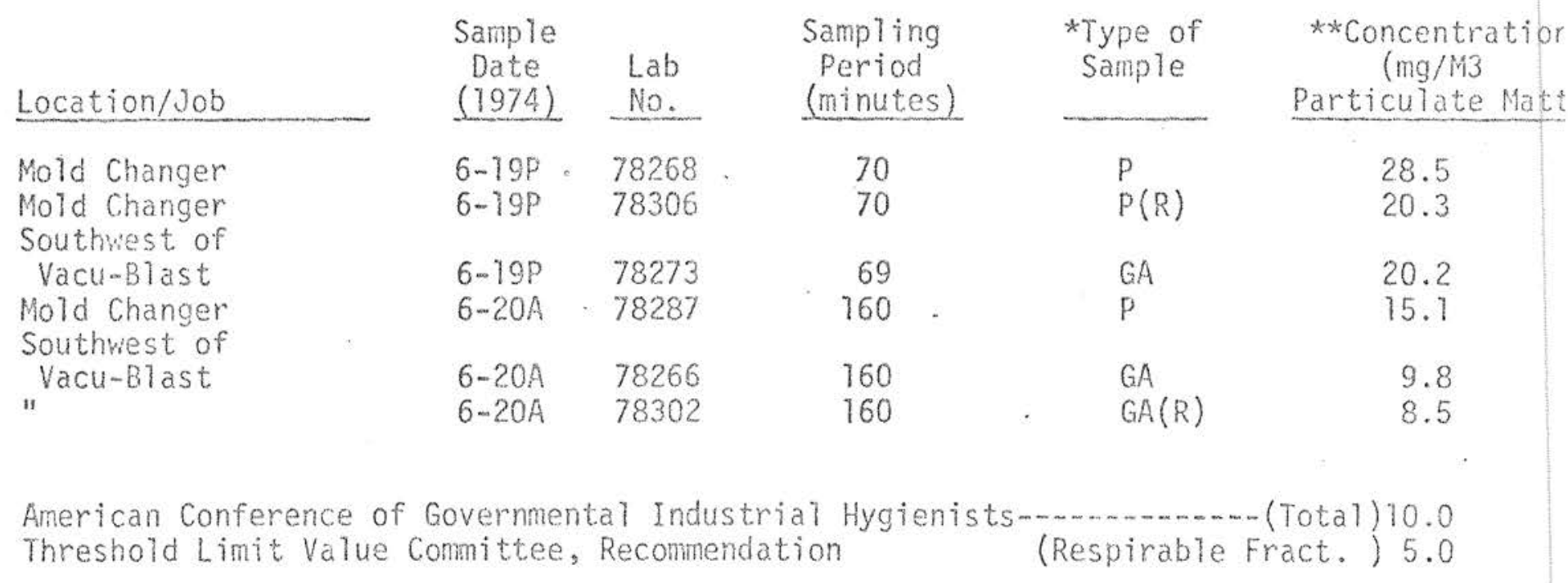

* P - Personal/Total Dust; $P(R)$ - Personal/Respirable Dust GA - General Area/Total Dust; $G A(R)$ - General Area/Respirable Dust

**mg 'M3 - milligrams of substance per cubic meter of air sampled 
Table 3

Concentrations of Zinc Oxide, Manganese and Copper

Dunlop Tire and Rubber Company Mill Room

Huntsville, Alabama

June $78-20,1974$

\begin{tabular}{|c|c|c|c|c|c|c|c|}
\hline ocation/Job & $\begin{array}{l}\text { Sample } \\
\text { Date } \\
(1974) \\
\end{array}$ & $\begin{array}{l}\text { Lab } \\
\text { No. }\end{array}$ & $\begin{array}{l}\text { Sampling } \\
\text { Period } \\
\text { (minutes) } \\
\end{array}$ & $\begin{array}{l}\text { *Type of } \\
\text { Sample }\end{array}$ & $\begin{array}{l}\text { Zinc Oxide } \\
(\mathrm{ZnO})\end{array}$ & $\begin{array}{l}\text { ation (mg } \\
\text { anganese } \\
\text { (Mn) }\end{array}$ & $\begin{array}{l}\text { Copper } \\
(\mathrm{Cu})\end{array}$ \\
\hline $\begin{array}{l}\text { \#1 Banbury(Scales) } \\
\text { " (weigh station) }\end{array}$ & $\begin{array}{l}6-18 P \\
6-18 P\end{array}$ & $\begin{array}{l}78274 \\
78284\end{array}$ & $\begin{array}{r}117 \\
98\end{array}$ & $\begin{array}{l}G A \\
G A\end{array}$ & $\begin{array}{l}1.10 \\
1.69\end{array}$ & $\begin{array}{l}0.002 \\
0.002\end{array}$ & $\begin{array}{l}0.003 \\
0.003\end{array}$ \\
\hline $\begin{array}{l}\text { \#1 Banbury (Oper.) } \\
\text { " } \\
\text { " (Oper.) } \\
\text { " (Comp.) } \\
\text { "(S. West of mixer) } \\
\text { "(level above) } \\
\text { "(level below) } \\
\text { \#3 Banbury (Oper.) } \\
\text { "(face of mixer) } \\
\text { "B" Mill } \\
\text { Machine Cleaner } \\
\text { AutocleanMach.Oper. } \\
\text { Fork Lift Operator } \\
\text { Utility Man }\end{array}$ & $\begin{array}{l}6-19 A \\
6-19 A \\
6-19 A \\
6-19 A \\
6-19 A \\
6-19 A \\
6-19 A \\
6-19 A \\
6-19 A \\
6-19 A \\
6-19 A \\
6-19 A \\
6-19 A \\
6-19 A\end{array}$ & $\begin{array}{l}78265 \\
78298 \\
78285 \\
78294 \\
78281 \\
78279 \\
78277 \\
78300 \\
78267 \\
78277 \\
78276 \\
78286 \\
78292 \\
78307\end{array}$ & $\begin{array}{r}134 \\
134 \\
60 \\
60 \\
361 \\
330 \\
153 \\
145 \\
324 \\
346 \\
144 \\
197 \\
139 \\
159\end{array}$ & $\begin{array}{l}P \\
P(R) \\
P \\
P(R) \\
G A \\
G A \\
G A \\
P(R) \\
G A \\
G A \\
P \\
P \\
P(R) \\
P(R)\end{array}$ & $\begin{array}{l}0.10 \\
0.05 \\
0.25 \\
0.13 \\
0.03 \\
0.04 \\
0.02 \\
0.01 \\
0.01 \\
0.01 \\
0.12 \\
0.10 \\
0.02 \\
0.12\end{array}$ & $\begin{array}{l}0.001 \\
0.001 \\
0.003 \\
0.003 \\
0.001 \\
0.001 \\
0.001 \\
0.001 \\
0.001 \\
0.001 \\
0.001 \\
0.001 \\
0.001 \\
0.001\end{array}$ & $\begin{array}{l}0.002 \\
0.002 \\
0.005 \\
0.005 \\
0.002 \\
0.002 \\
0.002 \\
0.002 \\
0.002 \\
0.002 \\
0.002 \\
0.002 \\
0.002 \\
0.002\end{array}$ \\
\hline $\begin{array}{ll}\text { \#1 Banbury } & \text { (Oper.) } \\
" & \text { (Oper.) } \\
" 1 & \text { (Comp.) } \\
\text { "(S. West of mixer) } \\
\text { \#2 Banbury (Oper.) } \\
\text { \#3 Banbury (Oper.) } \\
\text { " Machine Cleaner } \\
\text { Utility Man } \\
\text { Utility Man } \\
\text { Mezanine } \\
\text { "A"Mill (Oper.) } \\
\text { "B" Mill (Oper.) }\end{array}$ & $\begin{array}{l}6-19 p \\
6-19 p \\
6-19 p \\
6-19 p \\
6-19 p \\
6-19 p \\
6-19 p \\
6-19 p \\
6-19 p \\
6-19 p \\
6-19 p \\
6-19 p \\
6-19 p \\
6-19 p\end{array}$ & $\begin{array}{l}78269 \\
78305 \\
78282 \\
78293 \\
78290 \\
78295 \\
78270 \\
78308 \\
78278 \\
78283 \\
78289 \\
78261 \\
78299 \\
78297\end{array}$ & $\begin{array}{l}127 \\
127 \\
121 \\
127 \\
124 \\
140 \\
132 \\
132 \\
118 \\
125 \\
133 \\
60 \\
136 \\
130\end{array}$ & $\begin{array}{l}P \\
P(R) \\
P \\
P(R) \\
G A \\
P(R) \\
P \\
P(R) \\
P \\
P \\
P \\
G A \\
P(R) \\
P(R)\end{array}$ & $\begin{array}{l}0.16 \\
0.04 \\
1.07 \\
0.67 \\
0.18 \\
0.02 \\
0.04 \\
0.01 \\
0.02 \\
1.29 \\
0.57 \\
0.87 \\
0.01 \\
0.03\end{array}$ & $\begin{array}{l}0.001 \\
0.001 \\
0.001 \\
0.001 \\
0.001 \\
0.001 \\
0.001 \\
0.001 \\
0.002 \\
0.001 \\
0.001 \\
0.001 \\
0.001 \\
0.001\end{array}$ & $\begin{array}{l}0.002 \\
0.002 \\
0.002 \\
0.002 \\
0.002 \\
0.002 \\
0.002 \\
0.002 \\
0.003 \\
0.002 \\
0.002 \\
0.002 \\
0.002 \\
0.002\end{array}$ \\
\hline $\begin{array}{l}\text { \#) Banbury (Comp.) } \\
\text { " (Scales) } \\
\text { \#3 Banbury (Stack) } \\
\text { Banbury Trucker }\end{array}$ & $\begin{array}{l}6-20 A \\
6-20 A \\
6-20 A \\
6-20 A\end{array}$ & $\begin{array}{l}78275 \\
78288 \\
78303 \\
78291\end{array}$ & $\begin{array}{l}171 \\
182 \\
115 \\
151\end{array}$ & $\begin{array}{l}P \\
G A \\
P(R) \\
P\end{array}$ & $\begin{array}{l}0.16 \\
0.07 \\
0.02 \\
0.04\end{array}$ & $\begin{array}{l}0.001 \\
0.001 \\
0.002 \\
0.001\end{array}$ & $\begin{array}{l}0.002 \\
0.002 \\
0.003 \\
0.002\end{array}$ \\
\hline reshold Limit $\mathrm{Va}$ & & & & & & $5.0(\mathrm{c}) *$ & 0.2 \\
\hline
\end{tabular}

* P - Personal/Total Dust; $P(R)$ - Personal/Respirable Dust
$G A$ - General Area/Total Dust

$*_{*}^{*}$ - mg/M3 - milligrams of substance per cubic meter of air sampled

$* * *$ - ceiling value, not to be exceeded at any time during an 8-hour shift 